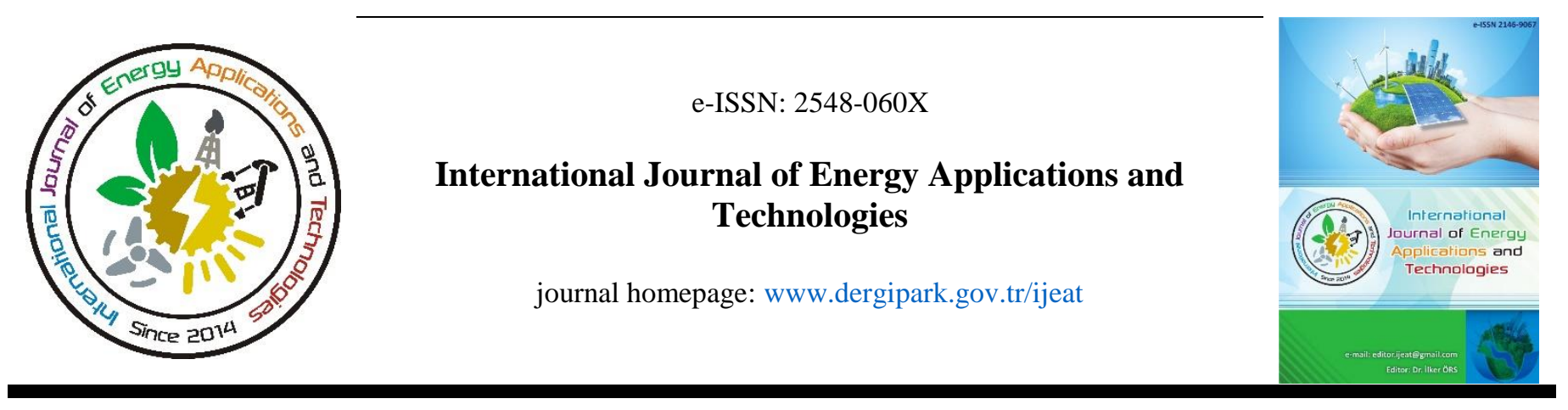

Original Research Article

\title{
Investigation of the combustion and fuel properties of slurry fuels formed by biomass and coal
}

\author{
Okan Kon, İsmail Caner ${ }^{*}$ \\ Balikesir University, Engineering Faculty, Department of Mechanical Engineering, Cagis Campus, 10145 Balikesir, Türkiye
}

\author{
ARTICLE INFO \\ * Corresponding author \\ ismail@balikesir.edu.tr \\ Received May 17, 2021 \\ Accepted October 27, 2021 \\ Published by Editorial Board \\ Members of IJEAT \\ (C) This article is distributed by \\ Turk Journal Park System under \\ the CC 4.0 terms and conditions.
}

\begin{abstract}
In the study, the combustion and fuel properties of slurry fuels, which are formed by mixing biomass as agricultural waste, sludge swage and algae, and coal as lignite and anthracite in certain proportions, were investigated. The energy properties of new slurry fuels were compared with fossil fuels such as lignite and anthracite, according to the Van Krevelen diagram used. The required stoichiometric air-fuel ratio (SAFR) amount in the burner was calculated during the combustion process. The real fuel-air ratio (RFAR) amount in the burner was determined during the combustion process according to the excess air coefficient $(\lambda)$ value of 1.5.; as agricultural waste Rice Husks (RH), Corn Cobs (CS), Walnut Shells (WS), Sunflower Shells (SS), Olive Cake (OC), Woodchips (WC) and as other biomass; Brown algae, sewage sludge have been used. As lignite, eight different types with low fuel properties and anthracite, which is the best coal fuel, were used. In the study, the H/C ratio was found to be 1.126 for the mixture of Anthracite + Sewage Sludge + Sunflower Shells (SS) depending on the sewage sludge for the slurry fuels mixture. If it is dependent on Algae, a value of 1.243 was calculated for the mixture of Muğla Ikizköy + Algae + Sunflower Shells (SS). The O/C ratio was found to be 0.242 for Anthracite + Sewage Sludge + Olive Cake (OC) depending on the sewage sludge for the slurry fuels mixture. For Algae, a value of 0.129 was calculated for the mixture of Anthracite + Algae + Olive Cake (OC).
\end{abstract}

Keywords: Slurry fuels, Biomass, Combustion, Stoichiometric air fuel ratio, Excess air coefficient

\section{Introduction}

Significant environmental pollution occurs with the use of fossil fuels. The main reason for the increase in the temperature on the earth's surface with global warming is the release of carbon dioxide $\left(\mathrm{CO}_{2}\right)$ and similar gases from the use of fossil fuels. Due to global warming, there are significant changes in the world's climate and human health is directly affected [1].

The use of large-scale incineration plants with biomass instead of traditional fossil fuels is of great importance in terms of meeting the energy needs of the society. In addition, the development of new technologies for the use of biomass opens up new opportunities for economic recovery and growth [2].
A combustion is a chemical event that releases heat as a result of the reaction of fuel with oxygen. During this reaction, the chemical energy in the fuel is released. Most of this released energy is converted into heat. Theoretically, the minimum amount of air required for complete combustion of a fuel is called stoichiometric air, and the combustion process in this way is called stoichiometric combustion. This air, which is used in more than the stoichiometric amount, is called excess air. The amount of air used in combustion can be represented by the excess air coefficient $\lambda$. The excess air coefficient is found by dividing the actual air-fuel ratio by the stoichiometric air-fuel ratio [3]. In order to ensure complete combustion, the actual amount of air sent to the combustion chamber should always be slightly more than the theoretical 
amount of air. Whether or not the combustion is complete in an enterprise plays an important role in the economy of that enterprise. Naturally, for bad combustion, the losses will increase and the heat economy will be very low. In practice, more air than stoichiometric air is often required [4].

The use of these low quality lignites in combustion systems without any improvement creates an important environmental problem in terms of high emissions. One of the technologies to reduce emissions is the combustion of lignite and biomass with an appropriate technology. Thus, due to the advantages of biomass, such as low ash and sulphur content, using $\mathrm{CO}_{2}$ while growing biomass, and being a renewable energy source, they will make a significant contribution to reducing overall emissions in combustion systems [5].

The decrease in hydrogen and oxygen decreases the $\mathrm{O} / \mathrm{C}$ and $\mathrm{H} / \mathrm{C}$ ratios of the biomass. The Van Krevelen diagram is drawn depending on the $\mathrm{O} / \mathrm{C}$ and $\mathrm{H} / \mathrm{C}$ ratios; is used to compare coal produced under various operating conditions and mixed with biomass with fossil-based coals (lignite). The Van Krevelen diagram also provides very valuable information in terms of determining the reactions that take place during carbonization $[1,5]$.

When the previous studies are examined, Çomaklı $\mathrm{K}$ and Yüksel B revealed that low-quality fuel consumption and increasing energy demands for space heating for Erzurum, the coldest city of Turkey, cause very high air pollution and sometimes poor air quality during the heating period. Therefore, in their study, they investigated the environmental effects of thermal insulation used to reduce heat losses in buildings [6]. Kuznetsov G.V., gave the results of experimental studies of a new fuel class bio-water-coal fuel (BioWCF) firing processes, whose main components were various degrees of metamorphism, water, and forest combustible material coals [7]. K.Y.U. Vershinina, et al., compared the slurry ignition and combustion parameters in addition to lignite, bituminous coal, and anthracite particles. They also investigated the combustion properties of conventional fossil fuels and coal-water slurry, coal processing waste, and waste-derived slurry [8]. Engin B, et al, conducted extensive experimental research on the combustion of low-grade Turkish lignites in a $30 \mathrm{kWth}$ circulation fluidized bed combustor. In the study, 18 lignite samples obtained from various lignite fields in Turkey were burned under similar combustion conditions in order to achieve combustion stability and to determine the emissions of major pollutants such as $\mathrm{CO}, \mathrm{NO}_{\mathrm{X}}$, and $\mathrm{SO}_{2}$ in the flue gas from the combustion chamber. The qualities of lignite were evaluated according to the Van Krevelen graph, which is highly dispersed and varied according to the degree of aging [9]. Elorf A., and Sarh B., examined the effect of excess air ratio $(\lambda)$ on the combustion dynamics of kiln pulverized olive pulp (OC) and different excess air ratios (EAR) $(\lambda=1.3,1.7$, 2.3 and 2.7 , respectively) for different situations for entry conditions [2]. Yumak T. investigated the effects of primary experimental variables such as test temperature, test duration, and biomass/water ratio and secondary test variables such as pre-pressure and catalyst usage on biochar yield in the production of biochar from various biomass by hydrothermal carbonization technique. In the study, Alpagut lignites and hazelnut shells, and olive pomace which have a serious waste potential in our country, and algae (Spirulina) were used as examples of water-type biomass [1]. Keivani B. investigated the biochar production of red pine sawdust and the combustion of biomass and coal mixtures in a fluidized bed combustion system [5]. Önal M. examined the parameters that affect the emission values of household burners to reduce emissions and achieve efficient combustion, such as fuel type, fuel flow, injector, the distance between injector and venturi channel inlet, venturi channel, mixing chamber, burner ports, and ambient temperature [3]. G.S. Nyashina et al. carried out experimental studies on the generation and evaluation of the most dangerous emissions (sulphur and nitrogen oxides) from the combustion of coal slurry fuels with straw, sunflower, and algae additives. A comparative analysis was conducted to determine the differences in sulfur and nitrous oxide concentrations from typical coal combustion, coal processing waste, as well as fuel slurries with and without plant additives [10]. İlbaş M. and Yılmaz İ. investigated the effect of excess air coefficient on combustion efficiency and emissions. In the study, two different fuels were burned in three different liquid fuel boilers and the boiler combustion efficiency and emission behavior were experimentally investigated at different radial distances from the smoke channel [4]. Toraman O. Y., et al, investigated the circulating fluidized bed (CFB) combustion properties of sewage sludge (SS) produced at a plant in Turkey. In the study, mud+olive pulp and mud+lignite coal mixtures were burned separately. Various mud-lignite coal and mud-olive cake ratios $(5 / 95,10 / 90,15 / 85,20 / 80)$ were investigated. The components in the flue gas $\left(\mathrm{O}_{2}, \mathrm{SO}_{2}, \mathrm{CO}_{2}\right.$, $\mathrm{CO}, \mathrm{NO}_{\mathrm{x}}, \mathrm{C}_{\mathrm{m}} \mathrm{H}_{\mathrm{n}}$ ) and the temperature and pressure distributions along the fluidized bed were measured. Combustion efficiency of mud-olive pulp and mud lignite coal mixtures were calculated and optimum conditions were given for the operating parameters [11]. Yin C., et al. examined biomass-fired grate boilers, basic elements of ignition system and development, important combustion mechanism, recent advances in technology, most pressing issues, current research and development activities, and critical issues to be solved in the future [12]. Namkung H. et al. developed new synthetic fuels called hybrid sludge fuel (HSF) using bioliquid (molasses) impregnated with coal and sewage sludge and compared their properties with 
conventional fuels [13]. Lei K., et al. proposed a singleparticle $(400-500 \mu \mathrm{m})$ co-firing method to investigate the cocombustion properties of sewage sludge (SS) and bituminous coal (BC) in air and oxy-fuel conditions [14]. Vassilev S V, et al. made a comprehensive study of the phase-mineral transformations of organic and inorganic matter that occur during biomass combustion and investigated the composition of biomass and biomass ash (BA) and the general characteristics of the behavior of biomass during combustion [15]. Varol M, et al. investigated the co-firing of BursaOrhaneli lignite and sawdust mixtures containing 10\%, 30\% and $50 \%$ by weight to investigate the effect of excess air ratio $(\lambda)$ on flue gas emissions, wood shavings were used in a circulating fluidized bed burner. In the study, the optimum excess air ratios were determined as 1.18, 1.32 and 1.41 [16]. Atimtay AT and Varol M studied the combustion of olive pulp and charcoal mixtures in a bubbly fluidized bed. In the study, Tunçbilek lignite coal was used together with olive pulp for combustion tests. Combustion performances and emission properties of olive pulp and coal mixtures were investigated. Various co-combustion tests of coal and olive pulp were carried out at the mixture ratios of $25 \%, 50 \%$ and $75 \%$ by weight of the olive pulp in the mixture [17]. Çay, Y., and Gürel, A. E., analyzed the effect of insulation thickness applied to exterior walls on the emission of $\mathrm{CO}_{2}$ and $\mathrm{SO}_{2}$ emissions for four different climate zones of Turkey. In the study, it was determined that when the optimum insulation thickness is used, emissions are reduced by $62-92 \%$ depending on the city, fuel type and insulation material [18]. The aim of this study is to examine the fuel and combustion properties of slurry fuels, which are formed by mixing $10 \%$ of agricultural waste, $50 \%$ of sludge swage and algae and $40 \%$ of lignite or anthracite. These rates have been determined based on the information in the literature used in obtaining the slurry fuel mixture. For this mixture, the Van Krevelen diagram drawn depending on the $\mathrm{O} / \mathrm{C}$ and $\mathrm{H} / \mathrm{C}$ ratios was used. In the study, instead of the pollutants formed as a result of combustion, investigations were made in terms of fuel and combustion properties. Stoichiometric air and actual air quantities, which are one of the important operating conditions during the combustion process, were investigated. For this, calculations based on the excess air coefficients $(\lambda)$ have been made in the literature, generally ranging from 1.1 to 2.5. In this study, the excess air coefficient $(\lambda)$ was accepted as 1.5 . This excess air coefficient $(\lambda)$ ratio is the value required for the full combustion of coal, and this value is generally used in the literature for the combustion of coalbased fuels. Accordingly, the actual amount of air during combustion was determined.

\section{Material and Methods}

\subsection{Determination of chemical formulas of fuel mixes}

The total mass of $\mathrm{M}$ mixtures $\left(\Phi_{\text {mixT }}\right)$ is the sum of the individual masses of the mixes. The total mole amount of the mixture is $\left(\Omega_{\text {mixT }}\right)$ the sum of the individual molar amounts of the mixtures [19].

$$
\begin{gathered}
\Phi_{\text {mixT }}=\sum_{\mathrm{i}=1}^{\mathrm{M}} \Phi_{\mathrm{i}} \\
\Omega_{\text {mixT }}=\sum_{\mathrm{i}=1}^{\mathrm{M}} \Omega_{\mathrm{i}}
\end{gathered}
$$

The ratio of the individual mass amounts of the mixture to the mass amount of the total mixture is the mass ratio $\left(\mathrm{y}_{\Phi_{\mathrm{i}}}\right)$ is the mass ratio.

$$
\mathrm{y}_{\Phi \mathrm{i}}=\frac{\Phi_{\mathrm{i}}}{\Phi_{\mathrm{T}}}
$$

The ratio of the individual molar amounts of the mixture to the molar amount of the total mixture $\left(\mathrm{y}_{\Omega \mathrm{i}}\right)$ is the molar ratio.

$$
\mathrm{y}_{\Omega \mathrm{i}}=\frac{\Omega_{\mathrm{i}}}{\Omega_{\mathrm{T}}}
$$

Sum of the mass ratio $\left(\mathrm{y}_{\Phi \mathrm{i}}\right)$ and mole ratio $\left(\mathrm{y}_{\Omega \mathrm{i}}\right)$ is one.

$$
\begin{aligned}
& \sum_{1}^{\mathrm{M}} \mathrm{y}_{\Phi_{\mathrm{i}}}=1 \\
& \sum_{1}^{\mathrm{M}} \mathrm{y}_{\Omega_{\mathrm{i}}}=1
\end{aligned}
$$

The molar quantity (n) is equal to the divided by the molar weight (M) of a substance mass (m) [19].

$$
\mathrm{n}=\frac{\mathrm{m}}{\mathrm{M}}
$$

\subsection{Equations used in calculations}

Equation of combustion;

$$
\begin{array}{r}
\mathrm{C}_{\mathrm{a}} \mathrm{H}_{\mathrm{b}} \mathrm{O}_{\mathrm{z}} \mathrm{S}_{\mathrm{p}} \mathrm{N}_{\mathrm{q}}+\lambda \cdot \mathrm{A} \cdot\left(\mathrm{O}_{2}+3,76 \mathrm{~N}_{2}\right) \rightarrow \\
\text { a. } \mathrm{CO}_{2}+(\mathrm{b} / 2) \cdot \mathrm{H}_{2} \mathrm{O}+\text { p. } \mathrm{SO}_{2}+\text { B. } \mathrm{O}_{2}+\text { D. } \mathrm{N}_{2}
\end{array}
$$

Here $\mathrm{A}$ is the minimum amount of air required for the combustion process and $\lambda$ is excess air ratio $[6,19]$.

$$
A=\left(a+\frac{b}{4}+p-\frac{z}{2}\right)
$$

The molecular weight of fuel;

$$
M_{f}=12 a+b+16 z+32 p+14 q
$$

Stoichiometric air fuel ratio (SAFR);

$$
\mathrm{SAFR}=\frac{\mathrm{M}_{\mathrm{a}} \cdot 28.97}{\mathrm{M}_{\mathrm{f}}}
$$

Here, the molecular weight of air was taken as $28.97 \mathrm{~kg} / \mathrm{kmol}$ [2]. This value is the molecular weight of dry air.

Excess air ratio $(\lambda)$;

$$
\lambda=\frac{\mathrm{RFAR}}{\mathrm{SAFR}}
$$

Here, RFAR is the real fuel air ratio (RFAR) [2]. 


\subsection{Fuels and properties}

In the study, eight types of lignite with low carbon content; Manisa Imbat-1, Manisa Imbat-2, Mugla Tinaz, Mugla Husamlar, Mugla Ikizköy, Bursa Keles, Canakkale Can, Konya Ilgin were used in the study. Agricultural waste as biomass; Rice Husks (RH), Corn Cobs (CC), Walnut Shells (WS), Sunflower Shells (SS), Olive Cake (OC), Woodchips (WC) and Brown Algae, Sewage Sludge were used as other biomass. This is due to the abundance of agricultural wastes in our country. Table 1 shows chemical ratios of different coal and biomass (wt\%).

Table 1. The chemical ratios (wt\%) of different coal and biomass [8-11,15-17]

\begin{tabular}{|c|c|c|c|c|c|c|}
\hline \multicolumn{7}{|c|}{ Coal (Lignite) } \\
\hline \multirow[t]{2}{*}{ Fuel } & \multicolumn{6}{|c|}{ Chemical composition } \\
\hline & $\mathbf{C}$ & $\mathbf{H}$ & $\mathbf{N}$ & $\mathbf{O}$ & $\mathbf{S}$ & Other \\
\hline Manisa Imbat-1 & 43.72 & 3.05 & 0.84 & 11.19 & 0.92 & 40.28 \\
\hline Manisa Imbat-2 & 43.67 & 3.06 & 0.78 & 15.20 & 0.77 & 36.52 \\
\hline Mugla Tinaz & 19.50 & 1.39 & 0.60 & 7.44 & 2.50 & 68.57 \\
\hline Mugla Husamlar & 43.69 & 3.06 & 1.30 & 12.55 & 4.30 & 35.10 \\
\hline Mugla Ikizköy & 42.80 & 2.40 & 0.99 & 15.50 & 5.11 & 33.20 \\
\hline Bursa Keles & 51.03 & 4.02 & 1.17 & 11.54 & 1.97 & 30.27 \\
\hline Canakkale Can & 39.21 & 2.86 & 0.96 & 7.67 & 5.69 & 43.61 \\
\hline Konya Ilgin & 32.18 & 2.69 & 0.69 & 6.96 & 5.02 & 52.46 \\
\hline \multicolumn{7}{|c|}{ Coal (Antrasit) } \\
\hline Antrasit & 82.08 & 3.13 & 1.18 & 1.87 & 0.70 & 11.04 \\
\hline \multicolumn{7}{|c|}{ Biomass } \\
\hline Rice Husks (RH) & 49.30 & 6.10 & 0.80 & 43.60 & 0.08 & 0.12 \\
\hline Corn Cobs (CC) & 47.80 & 5.90 & 0.50 & 45.60 & 0.01 & 0.19 \\
\hline Walnut Shells (WS) & 49.80 & 6.20 & 1.40 & 42.40 & 0.09 & 0.11 \\
\hline Sunflower Shells (SS) & 50.40 & 5.50 & 1.10 & 42.90 & 0.03 & 0.07 \\
\hline Olive Cake (OC) & 51.40 & 5.80 & 1.30 & 36.90 & 0.08 & 4.52 \\
\hline Woodchips (WC) & 53.70 & 6.90 & 0.30 & 37.70 & 0.00 & 1.40 \\
\hline \multicolumn{7}{|c|}{ Other Biomass } \\
\hline Brown Algae & 46.60 & 6.40 & 6.15 & 35.09 & 0.70 & 5.06 \\
\hline Sewage Sludge & 24.71 & 5.82 & 3.18 & 23.60 & 0.36 & 42.33 \\
\hline
\end{tabular}

\section{Results and Discussion}

When the chemical contents of lignite are examined, the highest amount of carbon, hydrogen and oxygen is seen in Bursa Keles lignite. The lowest amount of carbon and hydrogen is observed in Mugla Tinaz lignite and the lowest amount of oxygen is observed in Konya Ilgin lignite. When the chemical content of Biomass as agricultural waste is examined, the highest amount of carbon and hydrogen is Woodchips (WC), and the highest amount of oxygen is Corn Cobs (CC). In other biomass, on the other hand, the amount of carbon, hydrogen and oxygen in Sewage Sludge is very low. These carbon, hydrogen and oxygen amounts are effective in the Van Krevelen diagram drawn depending on the $\mathrm{O} / \mathrm{C}$ and $\mathrm{H} / \mathrm{C}$ ratios used to determine the properties of the newly created slurry fuels. Anthracite is known as the best quality coal in the literature. The amount of carbon is high; the amount of hydrogen and oxygen is low. Based on these values, the $\mathrm{O} / \mathrm{C}$ and $\mathrm{H} / \mathrm{C}$ ratios were calculated as 0.017 and 0.458 , respectively. These calculated values are the lowest $\mathrm{O} / \mathrm{C}$ and $\mathrm{H} / \mathrm{C}$ ratios. This shows that the best quality coal type is anthracite. The highest $\mathrm{O} / \mathrm{C}$ and $\mathrm{H} / \mathrm{C}$ ratios were 0.72 and 2.83 Sewage Sludge, respectively. From this, it is understood that the biomass source with the lowest quality in terms of fuel properties is Sewage Sludge. In the study, O/C and H/C ratios are given in Figure 1. When the chemical contents of lignite are examined, the highest amount of carbon, hydrogen, and oxygen is seen in Bursa Keles lignite. The lowest amount of carbon and hydrogen is observed in Mugla Tinaz lignite and the lowest amount of oxygen is observed in Konya Ilgin lignite. When the chemical content of Biomass as agricultural waste is examined, the highest amount of carbon and hydrogen is Woodchips (WC), and the highest amount of oxygen is Corn Cobs (CC). In other biomass, on the other hand, the amount of carbon, hydrogen, and oxygen in Sewage Sludge is very low. These carbon, hydrogen, and oxygen amounts are effective in the Van Krevelen diagram drawn depending on the $\mathrm{O} / \mathrm{C}$ and $\mathrm{H} / \mathrm{C}$ ratios used to determine the properties of the newly created slurry fuels. Anthracite is known as the best quality coal in the literature. The amount of carbon is high; the amount of hydrogen and 
oxygen is low. Based on these values, the $\mathrm{O} / \mathrm{C}$ and $\mathrm{H} / \mathrm{C}$ ratios were calculated as 0.02 and 0.046 , respectively. These calculated values are the lowest $\mathrm{O} / \mathrm{C}$ and $\mathrm{H} / \mathrm{C}$ ratios. This shows that the best quality coal type is anthracite. The highest $\mathrm{O} / \mathrm{C}$ and $\mathrm{H} / \mathrm{C}$ ratios were 0.72 and 2.83 Sewage Sludge, respectively. From this, it is understood that the biomass source with the lowest quality in terms of fuel properties is Sewage Sludge. In the study, $\mathrm{O} / \mathrm{C}$ and $\mathrm{H} / \mathrm{C}$ ratios are given in Fig. 1.

For 40\% Lignite / Anthracite $+10 \%$ Biomass $+50 \%$ Sewage Sludge fuel mixture, the highest $\mathrm{H} / \mathrm{C}$ ratio was 1.954 with Muğla Tinaz + Woodchips (WC) + Sewage Sludge and the lowest amount with 1.126 Anthracite + Sewage Sludge + Sunflower Obtained in Shells (SS) mixture. This is because the difference in the amount of hydrogen and carbon is 0.526 and lower in the mixture of Anthracite + Sewage Sludge + Sunflower Shells (SS). The difference in the amount of hydrogen and carbon is much higher with Muğla Tinaz lignite + Woodchips (WC) + Sewage Sludge 2.029. Muğla Tinaz + Corn Cobs (CC) + Sewage Sludge was found to have the highest $\mathrm{O} / \mathrm{C}$ ratio with 0.582 and Anthracite + Olive Cake (OC) + Sewage Sludge with the lowest 0.242 . The reason for this is that the difference in the amount of hydrogen and oxygen is 2.847, which is lower in Muğla Tinaz + Corn Cobs (CC) + Sewage Sludge mixture. The difference in the amount of hydrogen and oxygen is much higher with anthracite + Olive Cake (OC) + Sewage Sludge value of 3.727. These are given in Figure 1. O/C and H/C variation graph for $40 \%$ Lignite / Anthracite $+10 \%$ Biomass $+50 \%$ Sewage Sludge fuel mixture is given in Fig. 2.

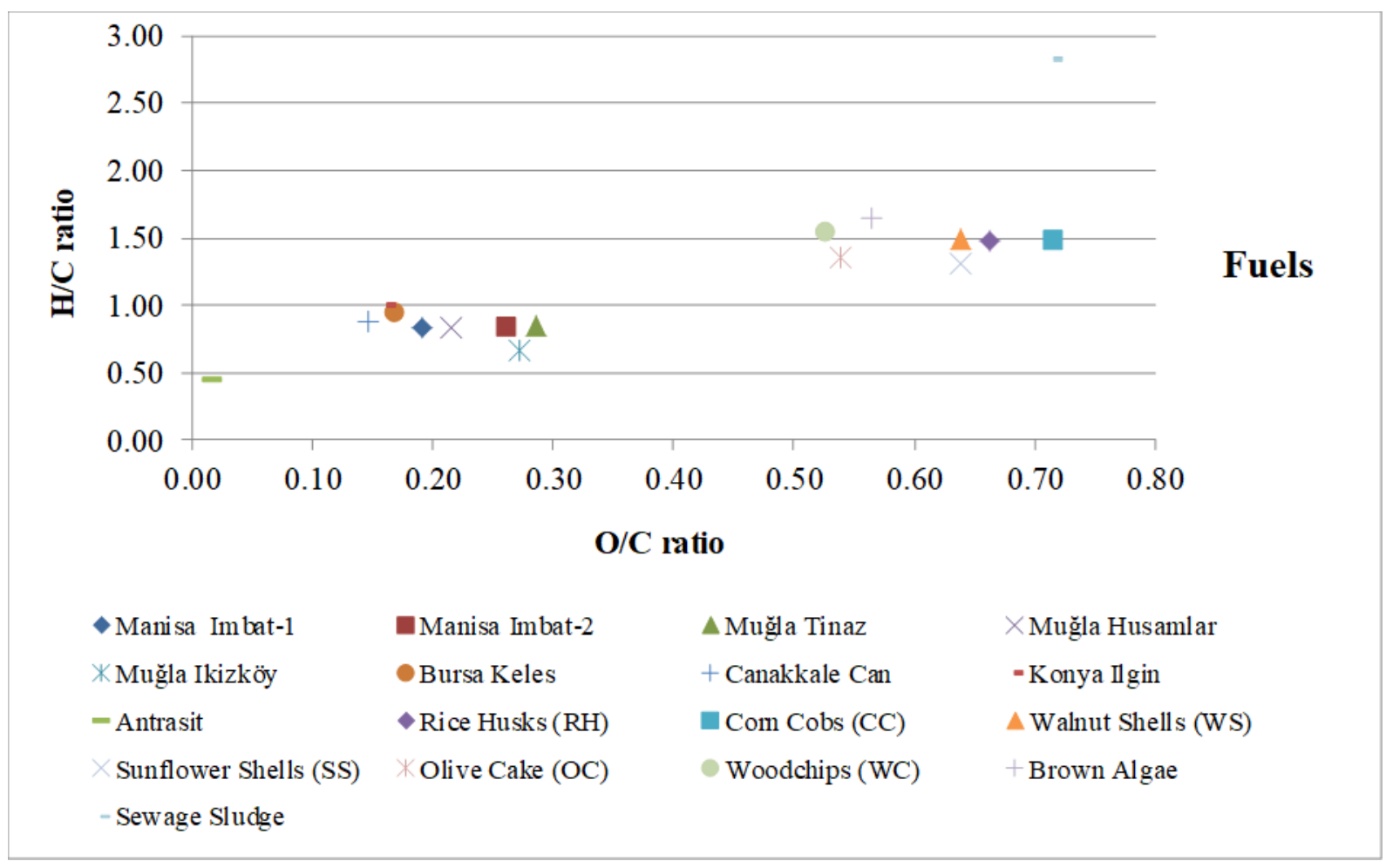

Fig. 1. O/C and H/C variation graph for different fuels

For $40 \%$ Lignite / Anthracite $+10 \%$ Biomass $+50 \%$ Algae fuel mixture, the highest $\mathrm{H} / \mathrm{C}$ ratio is 1.670 with Bursa Keles + Algae + Corn Cobs (CC) and the lowest amount with 1.243 Muğla Ikizköy + Algae + Sunflower Shells Obtained in (SS) mixture. The reason for this is that the difference in the amount of hydrogen and carbon is 1.357 and higher in Bursa Keles + Algae + Corn Cobs (CC) mixture. The difference in the amount of hydrogen and carbon is 0.922 , and Muğla Ikizköy + Algae + Sunflower Shells (SS) is much lower. Muğla Tinaz + Algae + Corn Cobs $(C C)$ had the highest $\mathrm{O} / \mathrm{C}$ ratio with 0.524 and Anthracite + Algae + Olive Cake (OC) with the lowest 0.129 . The reason for this is that the difference in the amount of hydrogen and carbon is 2.778 and higher in Muğla Tinaz + Algae + Corn Cobs (CC) mixture. The difference between hydrogen and oxygen amounts is 4.375 and Anthracite + Algae + Olive Cake (OC) is much more. These are given in Fig. 3 in the graph of $\mathrm{O} / \mathrm{C}$ and $\mathrm{H} / \mathrm{C}$ for $40 \%$ Lignite / Anthracite $+10 \%$ Biomass $+50 \%$ Algae fuel mixture. 
40\% Lignite / Anthracite + 10\% Biomass + 50\% Sewage Sludge

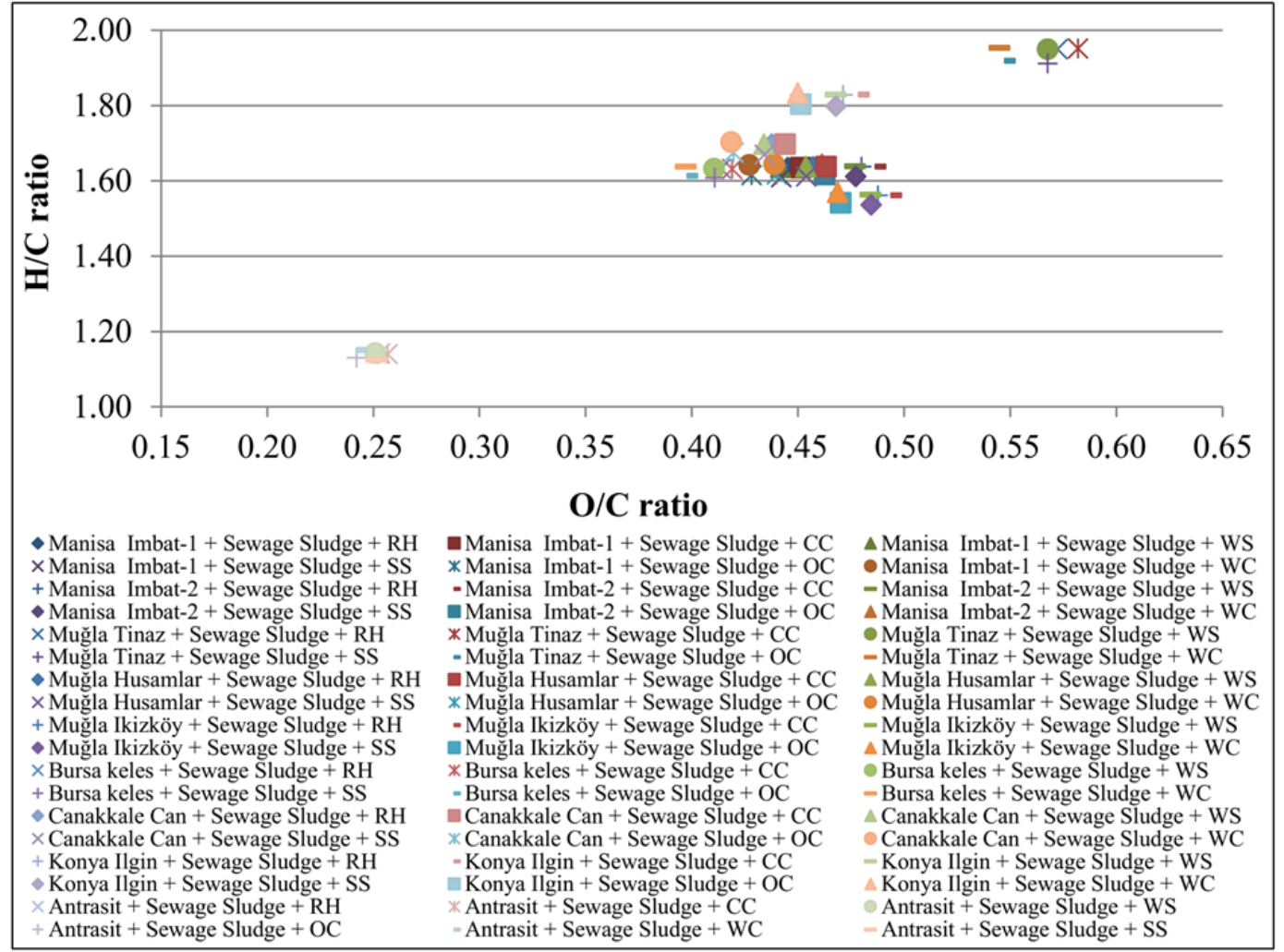

Fig. 2. O/C and H/C variation graph for $40 \%$ Lignite / Anthracite $+10 \%$ Biomass $+50 \%$ Sewage Sludge fuel mixture

40\% Lignite / Anthracite + 10\% Biomass + 50\% Algae

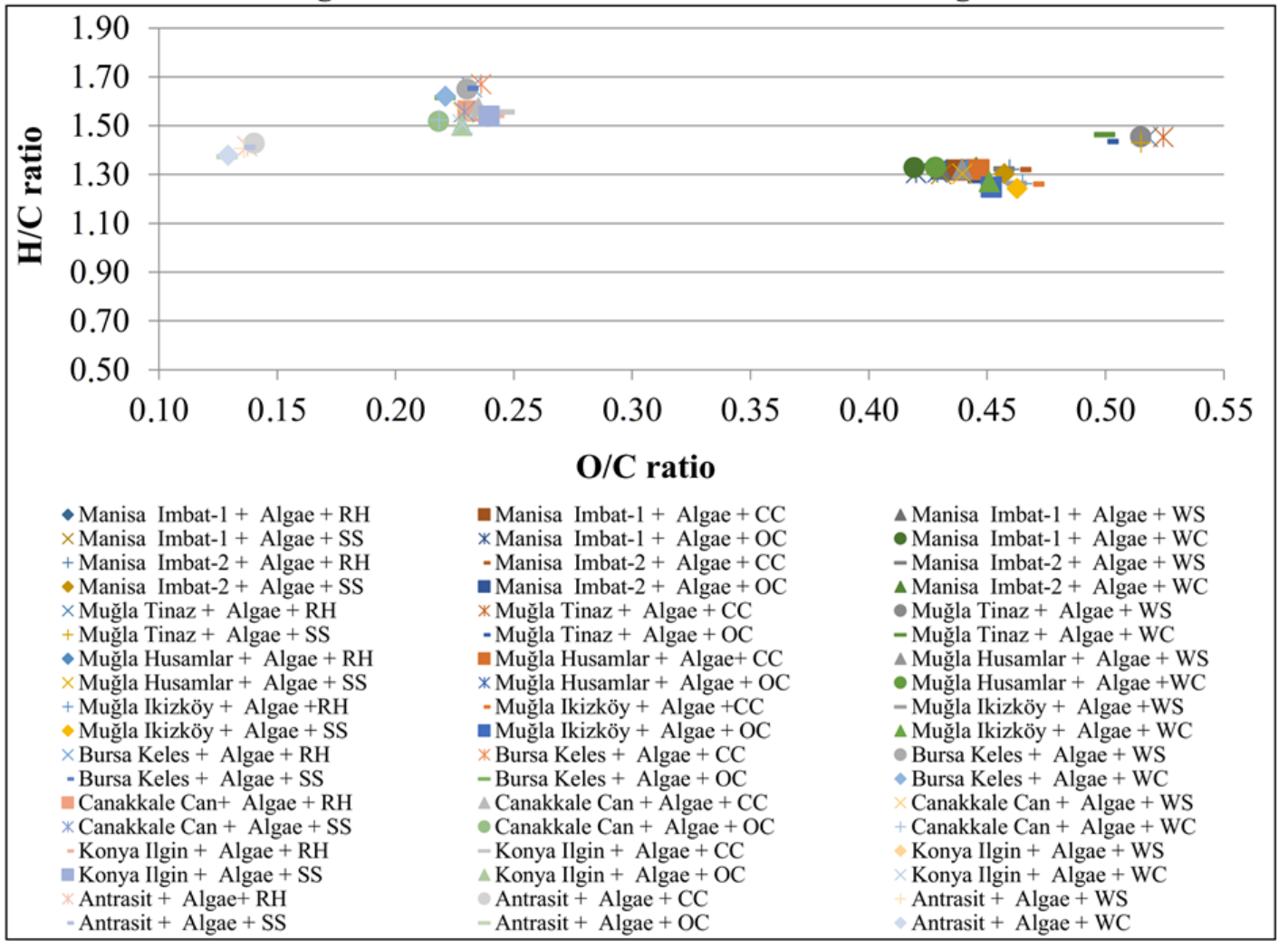

Fig. 3. $\mathrm{O} / \mathrm{C}$ and $\mathrm{H} / \mathrm{C}$ variation graph for $40 \%$ Lignite / Anthracite $+10 \%$ Biomass $+50 \%$ Algae fuel mixture 
When the fuels are considered individually rather than as a combination, the highest stoichiometric air-fuel ratio (SAFR) was calculated in anthracite with a value of 2.470 and the lowest value in Corn Cobs (CS) with a value of 1.171. The real fuel-air ratio (RFAR) ratio was also calculated with the highest value of 3.706 in Anthracite and the lowest in Corn Cobs (CS). The reason for this is that considering the excess air ratio $(\lambda) 1.5$ value for the Real fuel-air ratio (RFAR) value, the molar mass of the air required for the combustion of Anthracite is the highest with $219.766 \mathrm{~kg} / \mathrm{kmol}$. On the other hand, the molar mass of the air required for the combustion of Corn Cobs (CS) was calculated as $116,836 \mathrm{~kg} / \mathrm{kmol}$ at the lowest value. These values are given in Fig. 4.

When Sewage Sludge bonded fuel mixtures are taken into account, stoichiometric air-fuel ratio (SAFR) was calculated with the highest 1.923 in Anthracite + Sewage Sludge + Woodchips (WC). The lowest was found in Muğla Tinaz + Sewage Sludge + Corn Cobs (CC) mixture with 1.423. Real fuel-air ratio (RFAR), on the other hand, was calculated in Anthracite + Sewage Sludge + Woodchips (WC) with the highest value of 2.885, taking into account the excess air ratio ( $\lambda$ ) 1.5 value. The lowest was found in the mixture of Muğla Tinaz + Sewage Sludge + Corn Cobs $(C C)$ with a value of 2.134. The reason for this is that the molar mass of the air required for the combustion of the Anthracite + Sewage Sludge + Woodchips (WC) mixture is the highest with $142,822 \mathrm{~kg} / \mathrm{kmol}$. In Muğla Tinaz + Sewage Sludge + Corn Cobs (CC) mixture, the molar mass of the air required for combustion was calculated at the lowest value with 73.135 $\mathrm{kg} / \mathrm{kmol}$. These values are given in Fig. 5 .

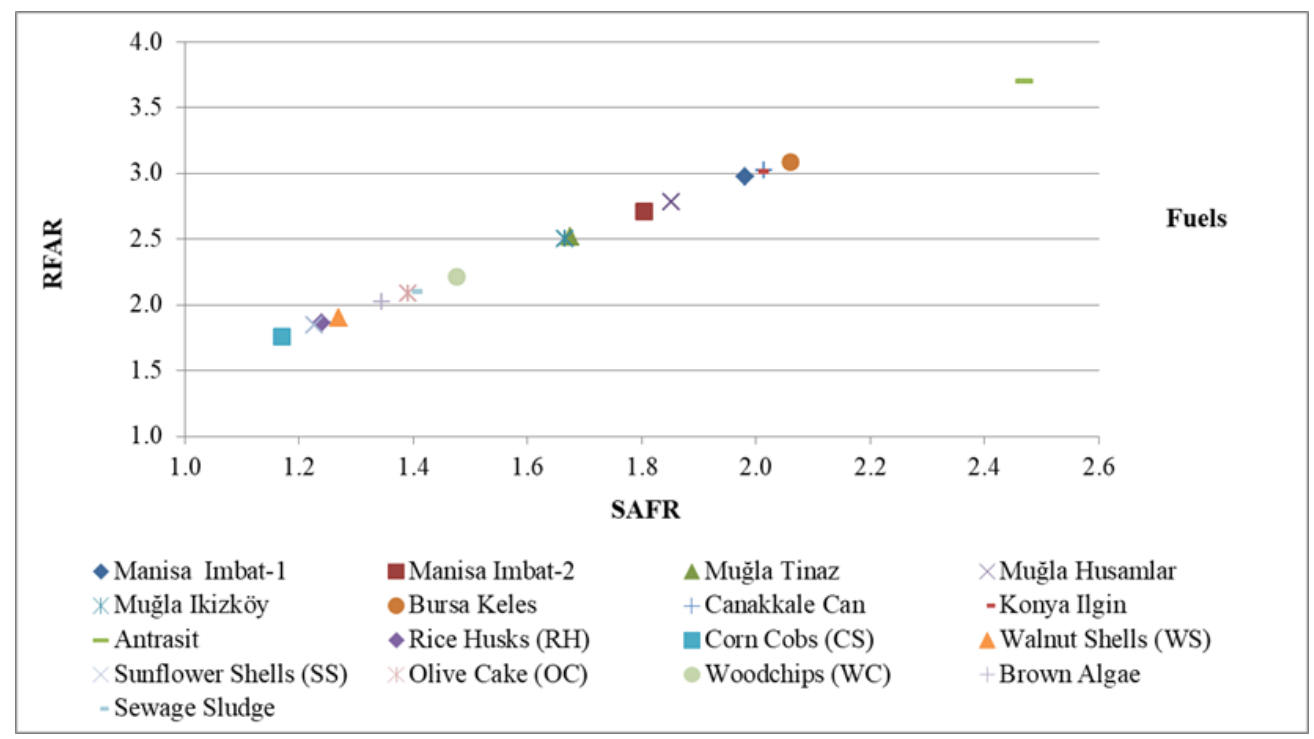

Fig. 4. The variation of stoichiometric air fuel ratio (SAFR) and real fuel air ratio (RFAR) for different fuels

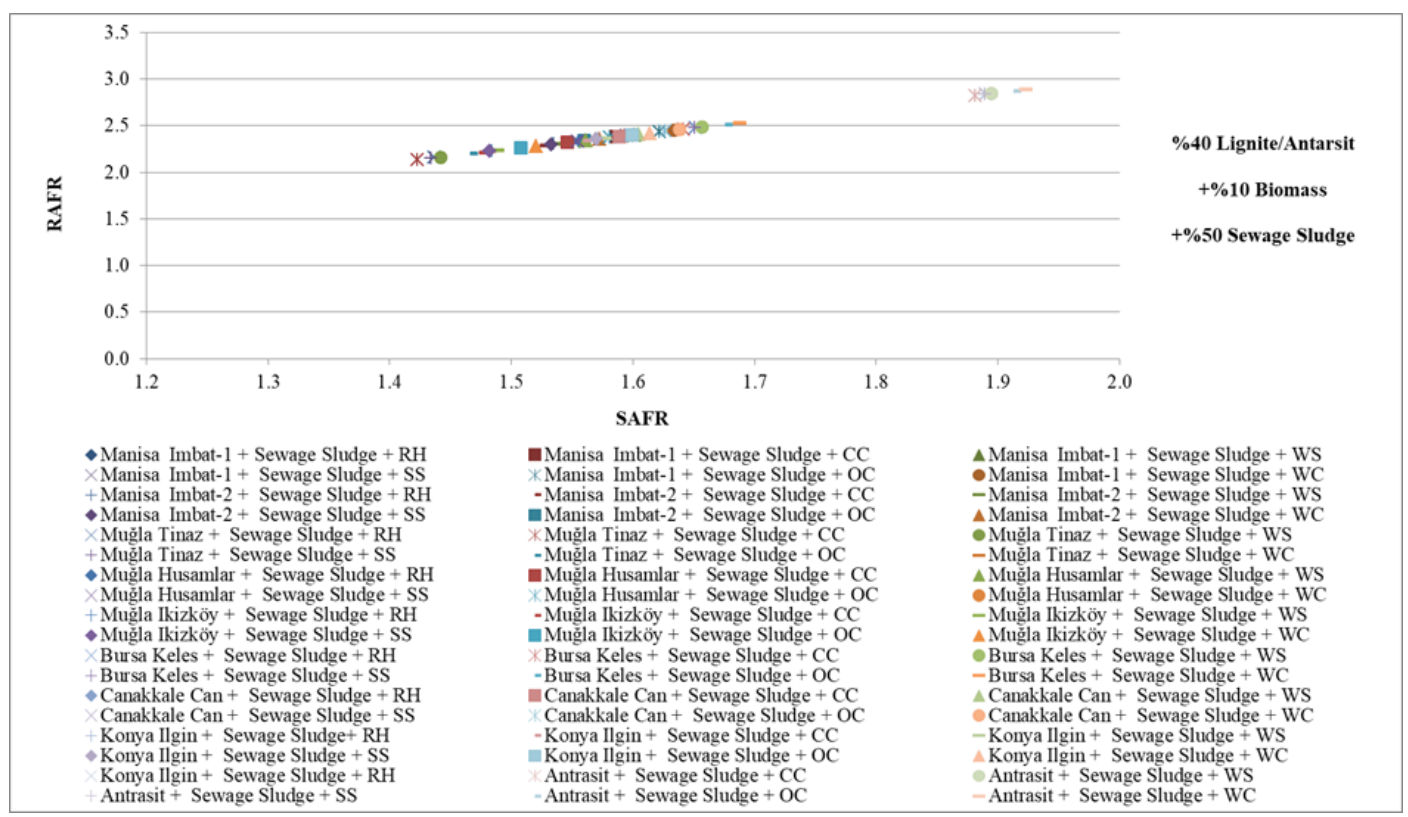

Fig. 5. For the $\% 40$ Lignite / Antrasit $+\% 10$ Biomass $+\% 50$ Sewage Sludge fuel mixture the stoichiometric air fuel ratio (SAFR) and real fuel air ratio (RFAR) variation graph 
Considering the fuel mixtures based on Algae, the stoichiometric air-fuel ratio (SAFR) was calculated with the highest 2.626 in Anthracite + Algae + Woodchips (WC). The lowest was found in Muğla Tinaz + Algae + Corn Cobs (CC) mixture with 1,829. Real fuel-air ratio (RFAR), on the other hand, was calculated by taking the excess air ratio $(\lambda)$ value of 1.5 into account, in the same way, with the highest 3.940 in Anthracite + Algae + Woodchips (WC). The lowest was found in the mixture of Muğla Tinaz + Algae + Corn Cobs (CC) with 2.744. The reason for this is that the molar mass of the air required for the combustion of the Anthracite + Algae + Woodchips (WC) mixture is the highest with 213,943 $\mathrm{kg} / \mathrm{kmol}$. In Muğla Tinaz + Algae + Corn Cobs (CC) mixture, the molar mass of the air required for combustion is calculated at the lowest value with $128.076 \mathrm{~kg} / \mathrm{kmol}$. These values are given in Fig. 6.

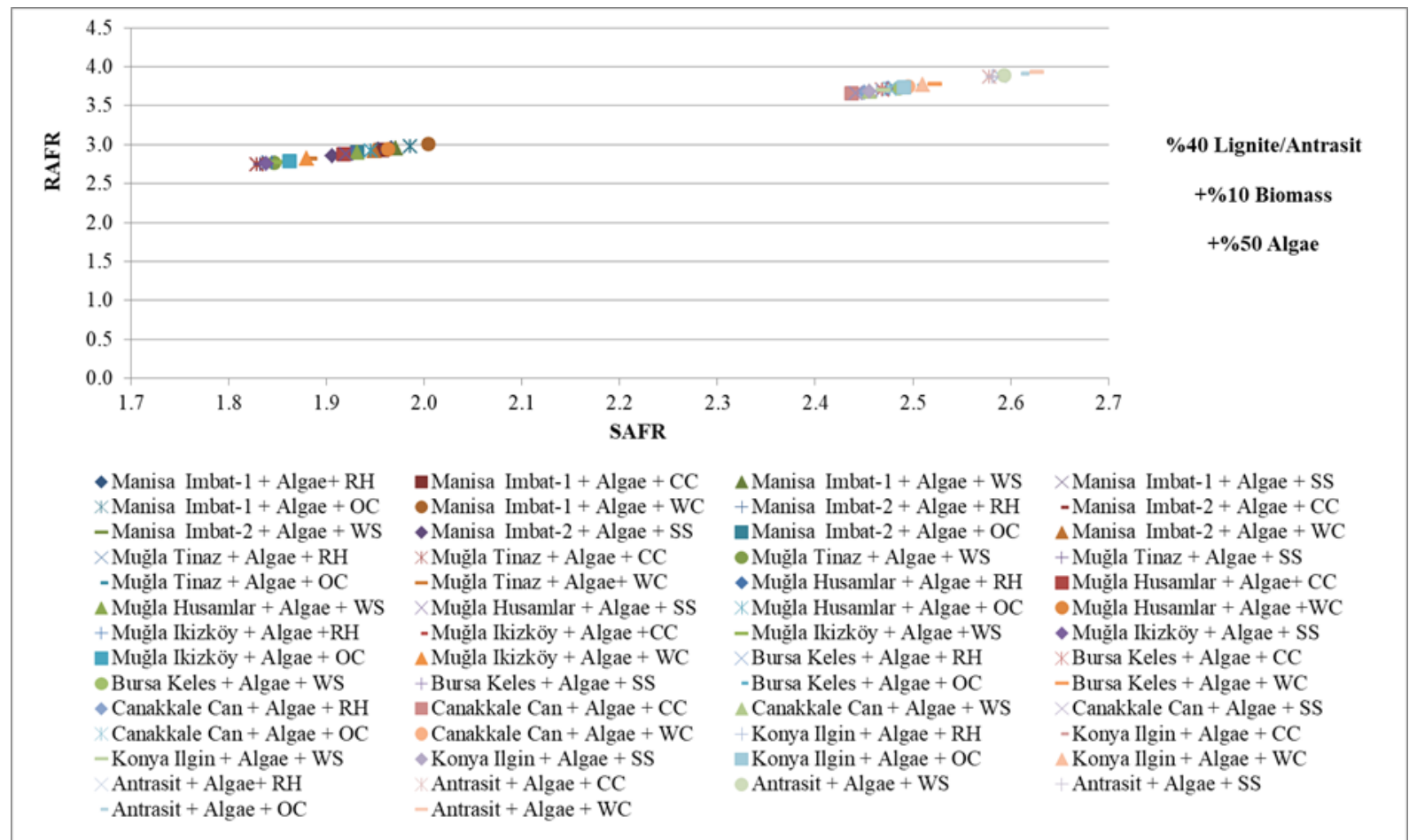

Fig. 6. For the $\% 40$ Lignite / Antrasit + \%10 Biomass + \% 50 Algae fuel mixture the stoichiometric air fuel ratio (SAFR) and real fuel air ratio (RFAR) variation graph

\section{Conclusion}

In the study, the lowest $\mathrm{H} / \mathrm{C}$ ratio of 0.458 and $\mathrm{O} / \mathrm{C}$ ratio of 0.017 were calculated in anthracite, which is known as the highest quality coal in the literature. Eight lignite types with the lowest known carbon content in Turkey were included in the study. Sewage sludge and algae were used for the slurry fuels mixture. Rice Husks (RH), Corn Cobs (CC), Walnut Shells (WS), Sunflower Shells (SS), Olive Cake (OC), Woodchips (WC) agricultural waste were accepted as biomass sources. Accordingly, a value of 1.126 was found for Anthracite + Sewage Sludge + Sunflower Shells (SS) depending on the sewage sludge for the slurry fuels mixture with the closest $\mathrm{H} / \mathrm{C}$ ratio to anthracite. Muğla Ikizköy + Algae + Sunflower Shells (SS) 1.243 value was calculated for the Algae mixture. Accordingly, the $\mathrm{O} / \mathrm{C}$ ratio closest to anthracite was found to be 0.242 for Anthracite + Sewage Sludge + Olive Cake (OC) depending on the sewage sludge for the slurry fuels mixture. Anthracite + Algae + Olive Cake (OC) 0.129 value was calculated for the Algae mixture. Depending on the Van Krevelen diagram where the H/C and
$\mathrm{O} / \mathrm{C}$ ratios are considered together, and as can be seen in the graphs given in the study, the sewage sludge and algae bound for the slurry fuels mixture, which is the closest to the best quality coal, antrasit as coal, and olive cake as agricultural waste ( OC) was found to be the best quality fuel for all lignite types in the study. Stoichiometric air-fuel ratio (SAFR) was calculated as 1.914 for Anthracite + Sewage Sludge + Olive Cake (OC) and 2.611 for Anthracite + Sewage Sludge + Olive Cake (OC). The real fuel-air ratio (RFAR) was found to be 2.870 for Anthracite + Sewage Sludge + Olive Cake (OC) and 3.917 for Anthracite + Sewage Sludge + Olive Cake (OC).

In the future, it will be considered to examine the combustion behaviour of new liquid fuels, which will be obtained with different ratios of biomass and fuel-oil mixture, depending on different air excess coefficients.

\section{$\underline{\text { ORCID }}$}

O. Kon

I. Caner

$0000-0002-5166-0258$ 0000-0003-1232-649X 


\section{References}

[1] Yumak T. 2016. Production and characterization of biochar obtained from different types of biomasses, $\mathrm{PhD}$ thesis, Ankara University, Graduate School of Natural and Applied Sciences, Department of Chemistry, Ankara, Türkiye.

[2] Elorf A., and Sarh B. 2019. Excess air ratio effects on flow and combustion caracteristics of pulverized biomass (olive cake), Case Studies in Thermal Engineering, 13, 100367.

[3] Önal M. 2017. Investigation of the performance effect of air fuel mixture on burner, MSc thesis, Yildiz Technical University, Graduate School of Natural and Applied Sciences, Department of Mechanical Engineering, İstanbul, Türkiye.

[4] İlbaşM. and Yılmaz İ. 2002. Farklı Isıl Güçlerdeki Kazanlarda Yanma ve Emisyon Davranışının Araştırılması, Erciyes Üniversitesi, Fen Bilimleri Enstitüsü Dergisi, 18(1-2), 18-27.

[5] Keivani B., Investigation of biocoal production and combustion of coal-biocoal mixtures in circulating fluidised bed under oxygen enriched environment, Ege University, Graduate School of Natural and Applied Sciences, 2018, Ph.D, Solar Energy Department, İzmir, Türkiye.

[6] Çomaklı K. and Yüksel B. 2004. Environmental impact of thermal insulation thickness in buildings. Applied Thermal Engineering, 24 5-6 933-940.

[7] Kuznetsov G.V., Malyshev D. Y., Kostoreva Z. A., Syrodoy S.V. and Gutareva N. Y. 2020. The ignition of the bio water-coal fuel particles based on coals of different degree metamorphism, Energy, 201117701.

[8] Vershinina K.Y.U., Dorokhov V.V., Romanov D.S. and Strizhak P.A. 2020. Comparing the ignition parameters of promising coal fuels, Process Safety and Environmental Protection, 139, 273-282.

[9] Engin B., Atakül H., Ünlü A. and Olgun Z. 2019. CFB combustion of low-grade lignites: Operating stability and emissions, Journal of the Energy Institute, 92, 542553.

[10] Nyashina G.S., Kuznetsov G.V. and Strizhak P.A. 2020. Effects of plant additives on the concentration of sulfur and nitrogen oxides in the combustion products of coal-water slurries containing petrochemicals, Environmental Pollution, 258, 113682.

[11] Toraman O. Y., Topal H., Bayat O. and Atimtay A. T. 2004. Emission Characteristics of Co-combustion of Sewage Sludge with Olive Cake and Lignite Coal in a Circulating Fluidized Bed, Journal of Environmental Science and Health, Part A Toxic/Hazardous
Substances and Environmental Engineering, 39(4), 973-986.

[12] Yin C., Rosendahl L. A. and Kær S. K. 2008. Gratefiring of biomass for heat and power production, Progress in Energy and Combustion Science, 34, 725754.

[13] Namkung H., Park J.-H., Lee Y.-J., Song G.-S., Choi J. W., Kim J.-G., Park J.-S., Um B. H., Song K. H., Park S.-J. and Choi Y.-C. 2017. Characteristics of novel synthetic fuels using coal and sewage sludge impregnated bioliquid applying for a coal combustion system, Fuel Processing Technology, 167, 153-161.

[14] Lei K., Zhang R., Ye B. Q., Cao J. and Liu D. 2018. Study of Sewage Sludge/Coal Co-Combustion by Thermogravimetric Analysis and Single Particle CoCombustion Method, Energy Fuels, 32, 6300-6308.

[15] Vassilev S. V., Baxter D. and Vassileva C. G. 2013. An overview of the behaviour of biomass during combustion: Part I. Phase-mineral transformations of organic and inorganic matter, Fuel, 112, 391-449.

[16] Varol M., Atimtay A. T., Olgun H. and Atakül H. 2014. Emission characteristics of co-combustion of a low calorie and high sulfur-lignite coal and woodchips in a circulating fluidized bed combustor: Part 1. Effect of excess air ratio, Fuel, 117, 792-800.

[17] Atimtay A. T. and Varol M. 2009. Investigation of cocombustion of coal and olive cake in a bubbling fluidized bed with secondary air injection, Fuel, 88, 1000-1008.

[18] Çay, Y. and Gürel, A. E. 2013. Determination of optimum insulation thickness, energy savings and environmental impact for different climatic regions of Turkey, Environmental Progress \& Sustainable Energy, 32(2), 365-372.

[19] Çengel Y. and Boles M. A. Mühendislik Yaklaşımı ile Termodinamik, McGraw-Hill, Literatür yayıncılı, (Çeviri Dertbentli, T.) Türkiye, 1996. 